\title{
Effects of graded levels of rumen-protected lysine on milk production in dairy cows
}

\author{
H Rulquin, C Hurtaud, L Delaby
}

INRA, Station de Recherches sur la Vache Laitière, 35590 Saint-Gilles, France

A positive relationship between level of postruminally infused lysine and milk protein content was established in dairy cows fed high-maize diets (Rulquin et al, 1990). A similar experiment was conducted using a larger number of cows fed increasing amounts of rumen protected lysine providing $0,15,30$, and $45 \mathrm{~g}$ of intestinal absorbable lysine.

Sixteen Holstein cows in their 5th week of lactation were assigned to a $4 \times 4$ latin square design comprising 3-week periods. The absorbable lysine/methionine ratio in protected 'lysine' was $3: 1$. Therefore rumen-protected methionine was added to the protected 'lysine' to keep the level of extra absorbable methionine constant $(15 \mathrm{~g} / \mathrm{d})$. The diet (DM basis: $66 \%$ maize silage, $34 \%$ concentrate) was offered to meet 100 and $120 \%$ of energy and protein requirements, respectively. The concentrate contained (DM basis): $20.4 \%$ dehydrated beet pulps; $17 \%$ barley; $17 \%$ fine wheat bran; $5.8 \%$ soybean meal; $21.9 \%$ maize gluten meal $60 ; 6.8 \%$ dehydrated alfalfa; $3.4 \%$ molasses; $0.7 \%$ fat; $0.4 \%$ urea; and $5.7 \%$ minerals. Maize protein accounted for $70 \%$ of total CP content of the diet (14.8\% DM).

Dry matter intake, milk yield, fat yield and content were not affected by the treatments. At the same time yields and contents of milk protein and casein increased significantly with lysine supply. However, these responses apparently declined when the lysine supplementation level exceeded $30 \mathrm{~g} / \mathrm{d}$.

It is concluded that the optimum supplemental absorbable lysine needs of dairy cows fed high maize diets are in the range of 15-30 $\mathrm{g} / \mathrm{d}$. Accurate determination of total lysine needs will require knowledge of basal dietary lysine fiow in the small intestine.

Rhône Poulenc Nutrition Animale is gratefully acknowledged for financial support.

Rulquin H, Le Henaff L, Vérité R (1990) Reprod Nutr Develop suppl 2, 238

Table I. Lactational responses to graded levels of rumen-protected lysine.

\begin{tabular}{|c|c|c|c|c|c|}
\hline & \multicolumn{4}{|c|}{ Absorbable lysine $(g / d)$} & \multirow[b]{2}{*}{ SED } \\
\hline & 0 & 15 & 30 & 45 & \\
\hline Intake (kg DM/d) & 21.7 & 22.2 & 22.1 & 22.2 & 0.7 \\
\hline Milk yield $(\mathrm{kg} / \mathrm{d})$ & 32.7 & 32.6 & 31.9 & 32.4 & 1.2 \\
\hline Fat yield $(g / d)$ & 1381 & 1377 & 1338 & 1370 & 71 \\
\hline Protein yield $(\mathrm{g} / \mathrm{d})$ & $1000^{a}$ & $1023 a b$ & $1025 a b$ & $1049 b$ & 37 \\
\hline Milk fat content $(\mathrm{g} / \mathrm{kg})$ & 42.4 & 42.2 & 42.4 & 42.6 & 2.6 \\
\hline Milk protein content $(g / \mathrm{kg})$ & $30.7 \mathrm{a}$ & $31.6 \mathrm{~b}$ & $32.3^{c}$ & $32.6 \mathrm{c}$ & 0.9 \\
\hline Milk casein content $(\mathrm{g} / \mathrm{kg})$ & $24.8^{a}$ & $25.7^{b}$ & $26.5^{c}$ & $26.6^{c}$ & 0.9 \\
\hline
\end{tabular}

$a, b, c$ Means in the same line with different superscripts differ at $P<0.05$. 